\title{
Pengaruh Media Permainan Monopoli Terhadap Kemampuan Berpikir Historis Siswa Kelas XI MIPA 8 SMA Negeri 1 Tasikmalaya
}

\author{
Ulfah Khoerun Nisa ${ }^{1}$, Oka Agus Kurniawan Shavab ${ }^{2}$, Iyus Jayusman ${ }^{3}$ \\ Mahasiswa Jurusan Pendidikan Sejarah Universitas Siliwangi ${ }^{1}$ \\ Dosen Jurusan Pendidikan Sejarah Universitas Siliwangi², 3 \\ Email: okaaks@unsil.ac.id,
}

\begin{abstract}
The purpose of this article writing is to find out the influence of monopoly game media on students' historical thinking ability on history subjects in the XI MIPA 8 class of SMA Negeri 1 Tasikmalaya even semester semester 2019/2020. The method used in this research is quasiexperimental with a quantitative approach. The design used is nonequivalent control group design. The population in this study were all students of class XI MIPA of SMA Negeri 1 Tasikmalaya which were divided into 9 classes. The sample in this study was determined using a purposive sample technique, namely class XI MIPA 8 as an experimental class and XI MIPA 9 as a control class. Data collected through observation and tests. The instruments used are observation guidelines and items in the form of descriptions with indicators of historical thinking. the number of description questions used is 7 items after validity testing. Data analysis techniques were performed using SPSS software version 25.0. The results showed that the use of monopoly games in class XI MIPA 8 had an effect on increasing the ability to think historically. This is based on the results of data processing which shows that the value of $t$ count $>t$ table $(6.248>2,000)$ or Sig $(2$-Tailed) value of $0.00<0.05$ so that Ho is rejected and $\mathrm{Ha}$ is accepted. The effectiveness of the monopoly game as a medium of learning in history subjects is stated to be quite effective in improving the historical thinking ability of students of class XI MIPA 8 of SMA Negeri 1 Tasikmalaya semester even academic year 2019/ 2020.
\end{abstract}

Keywords : Historical Thinking, Monopoly Game Media, History Lesson

\begin{abstract}
Penulisan artikel ini bertujuan untuk mengetahui pengaruh media permainan monopoli terhadap kemampuan berpikir historis siswa pada mata pelajaran sejarah di kelas XI MIPA 8 SMA Negeri 1 Tasikmalaya semester genap tahun ajaran 2019/ 2020. Metode yang digunakan dalam penelitian ini yaitu quasi eksperimen dengan pendekatan kuantitatif. Desain yang digunakan adalah nonequivalent control group design. Populasi dalam penelitian ini adalah seluruh siswa kelas XI MIPA SMA Negeri 1 Tasikmalaya yang terbagi dalam 9 kelas. Sampel dalam penelitian ini ditentukan dengan menggunakan teknik sampel purposif yaitu kelas XI MIPA 8 sebagai kelas eksperimen dan XI MIPA 9 sebagai kelas kontrol. Data dikumpulkan melalui observasi dan tes. Intrumen yang digunakan adalah pedoman observasi dan butir soal berbentuk uraian dengan indikator berpikir historis. jumlah soal uraian yang dipakai yaitu 7 butir soal setelah dilakukan uji validitas. Teknik analisis data dilakukan dengan menggunakan sofware SPSS versi 25.0. Hasil penelitian menunjukan bahwa penggunaan permainan monopoli di kelas XI MIPA 8 berpengaruh terhadap peningkatan kemampuan berpikir historis. Hal ini didasarkan pada hasil pengolahan data yang menunjukan bahwa nilai $t$ hitung $>t$ tabel $(6,248>2,000)$ atau nilai Sig (2-Tailed) 0,00 $<0,05$ sehingga Ho ditolak dan Ha diterima. Efektifitas
\end{abstract}


permainan monopoli sebagai media pembelajaran pada mata pelajaran sejarah dinyatakan cukup efektif dalam meningkatkan kemampuan berpikir historis siswa kelas XI MIPA 8 SMA Negeri 1 Tasikmalaya semester genap tahun ajaran 2019/ 2020.

Kata kunci : Berpikir Historis, Media Permainan Monopoli, Pelajaran Sejarah

\section{PENDAHULUAN}

Perubahan dalam proses pembelajaran diperoleh siswa melalui kegiatan berpikir. Dalam proses berpikir ini siswa memperoleh informasi dari seorang guru yang nantinya dari informasi tersebut memberikan perubahan dalam diri siswa, seperti perubahan dari hal yang awalnya tidak bisa menjadi bisa, perubahan dalam proses pemecahan suatu masalah, pengambilan suatu tindakan. Kemampuan berpikir tersebut mendorong siswa untuk mengembangkan kemampuannya sesuai dengan karakter siswa itu sendiri.

Pembelajaran sejarahpun tidak terlepas dari proses berpikir dan dalam pembelajaran sejarah dikenal kemampuan berpikir historis. Wineburg (2006:48) menjelaskan bahwa berpikir historis adalah berfikir dengan cara yang bertentangan dari cara berfikir sehari-hari yakni diharapkan mampu berpikir kritis, analitis sehingga dapat membaca buku sejarah dengan terampil, membaca peristiwa sesuai dengan konteks, berdiskusi, dan evaluasi. Hal lainnya ditambahkan oleh Sofiani dan Shavab (2018:117) bahwa berpikir historis merupakan kegiatan yang di dalamnya terdapat unsur menganalisis materi yang didapat seperti bagaimana membandingkan peristiwa sejarah yang satu dengan yang lainnya, kenapa peristiwa sejarah terjadi dan bagaimana dampaknya, bagaimana peristiwa sejarah dapat membantu untuk kehidupan saat ini dan mampu melakukan interpretasi terhadap peristiwa sejarah yang terjadi. 
Kemampuan berpikir historis ini bertujuan untuk meningkatkan mutu pembelajaran sejarah agar siswa mampu mengkritisi peristiwa masa lampau yang dikaitkan dengan isu-isu atau permasalahan dimasa sekarang. Kemampuan berpikir historis ini akan memberikan solusi terkait permasalahan yang ada dan bersumber pada pengalaman dan literatur kesejarahan untuk diambil nilai-nilai yang terkandung didalamnya. Berpikir historis juga membuat siswa aktif dalam proses pembelajaran dan mampu mengungkapkan ide-ide serta solusi terhadap permasalahan yang guru tawarkan.

Berdasarkan hasil observasi yang dilakukan pada kelas XI MIPA 8 SMA Negeri 1 Tasikmalaya, permasalahan yang ditemukan adalah rendahnya kemampuan berpikir historis siswa. Hal tersebut terlihat pada proses pembelajaran berlangsung, siswa jarang bertanya dan menanggapi argumen dari pernyataan atau pertanyaan yang diucapkan oleh guru. Kemampuan siswa terbatas hanya pada penalaran peristiwa sejarah saja yang menyerap secara pasif berupa fakta. Siswa tidak mengkritisi bagaimana suatu peristiwa sejarah itu sendiri dan kaitannya dengan masa sekarang sehingga siswa tidak tahu makna apa yang bisa diambil dari suatu peristiwa sejarah tersebut.

Model dan media pembelajaran dikemas terlalu konvensional yaitu dengan media powerpoint dengan slide yang cukup banyak dan huruf yang kecil. Hal ini membuat siswa cepat jenuh dan tidak tertarik yang menyebabkan tidak mengerti dengan materi yang diajarakan. Seperti yang diungkapkan oleh Shavab dan Miftahudin (2019:15) bahwa pembelajaran sejarah di kelas seharusnya menggunakan model/metode pembelajaran yang variatif. Hal lainnya adalah pembelajaran harus dapat menarik 
perhatian siswa, sehingga siswa menjadi lebih aktif dalam kegiatan pembelajaran. Dengan terjadinya hal ini, maka dapat mencapai tujuan pembelajaran yang telah ditetapkan.

Selain itu, dalam proses pembelajaran sejarah dengan media ini juga ada beberapa siswa yang tidur dan tidak mau memperhatikan pembelajaran. Sehingga keaktifan siswa yang seharusnya ada dalam proses pembelajaran juga tidak terlihat. Dari hal ini membuat siswa tidak mengerti dengan materi sejarah yang telah diajarkan. Ketika diberikan soal yang berisi penjabaran peristiwa sejarah ataupun analisis, interpretasi dan pemahaman konteks terhadap suatu peristiwa sejarah siswa kurang mampu mengerjakannya, dan bahkan banyak yang tidak mengisi jawaban dari soal-soal tersebut. Sehingga bisa disimpulkan bahwa dengan keadaan siswa yang demikian, secara otomatis kemampuan berpikir historis siswa kurang.

Hal tersebut dibenarkan oleh guru mata pelajaran Sejarah kelas XI yaitu Bapak Ali Dahlan, S.S. M.Pd, beliau mengatakan bahwa secara keseluruhan kemampuan berpikir historis siswa kelas XI MIPA 8 ini terbilang kurang. Indikator berpikir historis yaitu berpikir dalam konteks, kronologi dan kesinambungan, Interpretasi dan bukti serta memahami sebab akibat dirasa belum terpenuhi oleh siswa kelas XI MIPA 8. Selain itu, siswa juga kurang mampu membedakan antara fakta yang otentik atau sesuai dengan peristiwa sejarah dikarenakan kompetensi literasi yang masih kurang dengan sumber yang terbatas.

Berdasarkan permasalahan tersebut, maka disiapkan media pembelajaran baru yaitu media permainan monopoli dalam materi sejarah proklamasi kemerdekaan Indonesia sampai terbentuknya pemerintahan 
Indonesia yang diharapkan mampu membantu siswa dalam meningkatkan pemahaman dan kemampuan berpikir historis siswa. Media permainan monopoli ini dipilih karena termasuk suatu permainan yang relatif digemari dan disenangi oleh anak-anak sehingga dirasa akan membantu dalam proses pembelajaran. Selain itu, proses penyampaian informasi atau pembelajaran juga akan dengan mudah diterima oleh siswa melalui pengembangan intelektual yang dimiliki oleh siswa. Hal tersebut sejalan dengan yang dikemukakan oleh Ismail A. (2006:119) dalam Sumantri dan Yulianti (2019:439) "the game method is a fun activity and is an educational tool or tool that can be useful in develoving oneself completely". Situasi pembelajaran seperti ini membuat siswa terlibat langsung dalam proses pembelajaran karena terciptanya situasi pembelajaran yang menyenangkan. Hal ini sesuai dengan Sa'dun Akbar, dkk (2015) bahwa, fun learning is kind of learning process or experience which could make learners feel pleasure in a learning scenario/ process. Piaget dalam Bennett (2005:16) menambahkan bahwa permainan dapat memudahkan pembelajaran dengan mendorong anak agar bisa mengasimilasikan materi baru kedalam struktur kognitif yang telah ada.

Penggunaan media permainan monopoli memiliki kesesuaian fungsi kognitif dari penggunaan media pembelajaran terutama media visual. Menurut Levie dan Lentz dalam Arsyad (2007:17) Fungsi Kognitif, lambang visual atau gambar dapat memperlancar dalam memudahkan untuk mengingat, memahami atau mengingat informasi atau pesan yang terkandung dalam media visual yang disajikan.

Adapun perbedaan permainan monopoli yang digunakan dengan permainan monopoli pada umumnya adalah: 
1. Papan monopoli pada umumnya terdiri dari negara-negara dan perusahaan-perusahaan. Pada penelitian ini, hal tersebut diganti menjadi peristiwa-peristiwa yang disusun secara kronologis, menyesuaikan dengan materi yang akan diajarkan;

2. Perangkat permainan monopoli pada umumnya memiliki kartu dana umum, kartu kesempatan dan sertifikat sewa dan beli setiap negara. Pada penelitian ini, hal tersebut diganti menjadi kartu cerita, kartu penyelesaian dan kartu perpustakaan yang isinya sudah di setting materi proklamasi kemerdekaan sampai terbentuknya pemerintahan Indonesia dengan indikator-indikator berpikir historis;

3. Petak dalam permainan monopoli pada umumnya berjumlah 40 petak, sedangkan dalam permainan monopoli ini hanya 32 petak;

4. Perangkat uang dalam permainan monopoli ini dirancang dengan tokoh-tokoh yang seputar pengibaran bendera dan pembacaan proklamasi kemerdekaan Indonesia.

Berikut merupakan desain media permainan monopoli dengan materi sejarah proklamasi kemerdekaan sampai terbentuknya pemerintahan Indonesia:

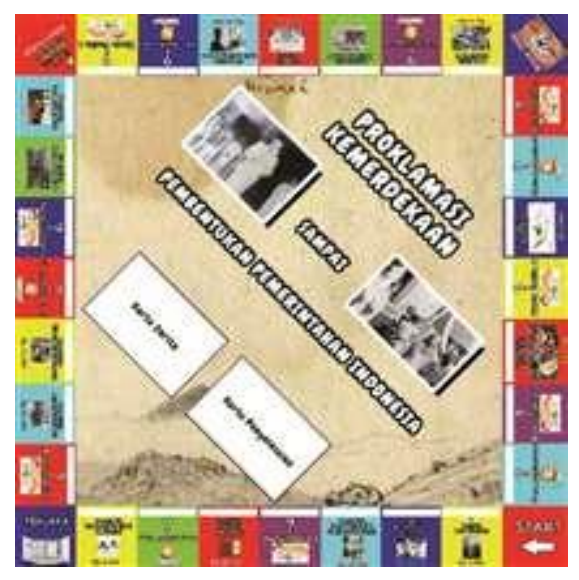


Gambar 1. Desain Media Permainan Monopoli

\section{METODE}

Metode penelitian yang digunakan adalah quasi eksperimen dengan pendekatan kuantitatif. Penggunaan metode penelitian quasi eksperimen dalam penelitian ini bertujuan untuk memperoleh informasi tentang peningkatan kemampuan berpikir historis dengan menggunakan media permainan monopoli. Desain penelitian yang digunakan adalah nonequivalent control group design.

Sample dalam penelitian ini adalah kelas XI MIPA 8 sebagai kelas eksperimen dan kelas XI MIPA 9 sebagai kelas kontrol. Untuk menentukan sample dalam penelitian ini menggunakan teknik sampel purposif. Sampel diambil atas pertimbangan rendahnya kemampuan berpikir historis dengan rata-rata hasil test dengan indikator berpikir historis berada pada nilai rata-rata $35-36$.

Instrumen yang digunakan dalam penelitian ini adalah butir soal dengan indikator berpikir historis serta pedoman observasi pembelajaran dengan menggunakan media permainan monopoli. Adapun rincian validitas instrumen soal bisa dilihat dalam tabel berikut:

Tabel 1. Instrumen Butir Soal Valid

\begin{tabular}{lllll}
\hline Soal & r Tabel & r Hitung & Indikator & Ket. \\
\hline 1 & 0,338 & 0,897 & Berpikir dalam Konteks & Valid \\
2 & 0,338 & 0,943 & Kronologi dan Kesinambungan & Valid \\
6 & 0,338 & 0,922 & Kemampuan memahami sebab akibat & Valid \\
11 & 0,338 & 0,537 & Kronologi dan kesinambungan & Valid \\
13 & 0,338 & 0,430 & Interpretasi dan bukti & Valid \\
14 & 0,338 & 0,391 & Interpretasi dan bukti & Valid \\
15 & 0,338 & 0,435 & Interpretasi dan bukti & Valid \\
\hline
\end{tabular}

Sumber: Hasil Pengolahan Data 
Setelah dilakukan uji validitas, selanjutnya yaitu uji reliabilitas. Adapun hasil uji reliasbilitas butir soal dengan SPSS adalah:

Tabel 2. Hasil Uji Reliabilitas

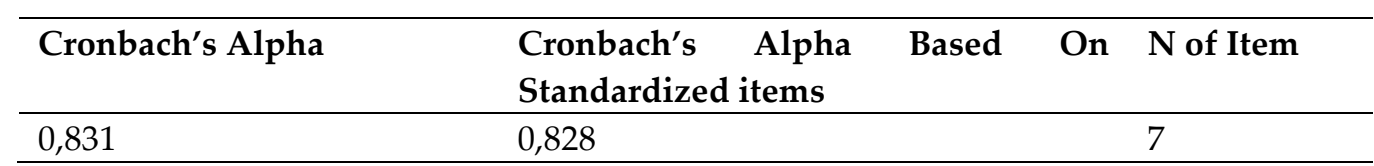

Sumber: Hasil Pengolahan Data

Berdasarkan hasil uji reliabilitas dari jumlah data yang valid sebanyak 7 soal menunjukan bahwa instrumen butir soal tersebut berada pada tingkat reliabilitas tinggi yaitu dengan Cronbach's Alpha 0,831.

\section{HASIL}

Pembelajaran kelas XI MIPA 8 sebelum menggunakan media permainan monopoli dilakukan dengan menggunakan model pembelajaran Discovery learning. Pembelajaran dilakukan dengan diskusi kelompok dan presentasi. Berdasarkan pengamatan yang dilakukan, pembelajaran terlihat kurang kondusif. Karena masih terdapat banyak siswa yang kurang antusias terhadap pembelajaran. Ketika pembawaan materi dilakukan oleh siswa yang menjelaskan dengan lantang maka siswa lainnya memperhatikan. Sedangkan ketika penjelasan dilakukan dengan suara pelan maka mereka kurang memperhatikan. Selain itu, ketika jalannya diskusi juga tidak semua siswa mengerjakan secara bersama-sama topik permsalahan yang telah diberikan oleh guru. Dampaknya terlihat saat dilakukan sesi tanya jawab yaitu tidak semua siswa dalam kelompok mampu berkontribusi dengan baik selama proses pembelajaran berlangsung.

Sebelum dilakukan pembelajaran dengan media permainan monopoli, dilakukan pre test terlebih dahulu baik di kelas eksperimen 
maupun di kelas kontrol. Pre test ini dilakukan dengan mengerjakan soal uraian sebanyak 7 soal dengan masing-masing soal sudah sesuai dengan indikator berpikir historis. Rata-rata pre test dari kelas eksperimen dan kelas kontrol sebelum dilakukannya treatment yaitu:

Tabel 3. Perbandingan Rata-rata Pretest Kelas Kontrol dan Kelas Eksperimen

\begin{tabular}{lll}
\hline \multirow{2}{*}{ Statistik } & \multicolumn{2}{c}{ Pretest } \\
\cline { 2 - 3 } & Kelas Kontrol & Kelas Eksperimen \\
\hline Rata-rata & 34,57 & 35,98
\end{tabular}

Sumber: Hasil Pengolahan Data

Selanjutnya, proses pembelajaran dengan menggunakan media permainan monopoli di kelas eksperimen dilakukan sebanyak dua kali pertemuan. Pembelajaran dengan media permainan monopoli ini dilakukan mengikuti model Team Games Tournament. Pada pertemuan pertama, guru membagi siswa ke dalam 6 kelompok heterogen. Masingmasing kelompok berdiskusi dan belajar dengan menggunakan media permainan monopoli. Pembelajaran dengan media permainan monopoli di pertemuan pertama dilakukan sebanyak 5 kali putaran, sedangkan untuk pertemuan kedua sebanyak 9 kali putaran. Terhitung dari setiap perwakilan kelompok yang bermain ke depan. Ketika guru menghentikan permainan, siswa nampak kecewa dan ingin terus bermain atau belajar dengan menggunakan permainan monopoli ini. Namun, meskipun dengan waktu yang cukup singkat materi-materi dengan indikator berpikir historis sudah cukup terbahas dan dimengerti oleh siswa.

Setelah proses pembelajaran, dilakukan post test untuk mengukur kemampuan berpikir historis siswa di kelas eksperimen yang 
menggunakan media monopoli dan di kelas kontrol dengan media powerpoint.

Tabel 4. Perbandingan Rata-rata Pos ttest Kelas Kontrol dan Post test Kelas Eksperimen

\begin{tabular}{lll}
\hline \multirow{2}{*}{ Statistik } & \multicolumn{2}{c}{ Post Test } \\
\cline { 2 - 3 } & Kontrol & Eksperimen \\
\hline Rata-rata & 64,38 & 81,16
\end{tabular}

Sumber: Hasil Pengolahan Data

Berdasarkan tabel tersebut, maka rata-rata hasil post test kelas XI MIPA 9 sebagai kelas kontrol yaitu 64,38. Sedangkan, untuk rata-rata posttest kelas XI MIPA 8 sebagai kelas eksperimen yaitu 81,16. Hasil post test dari kedua kelas tersebut mengalami peningkatan setelah adanya perlakuan, sehingga disini dapat disimpulkan bahwa kemampuan berpikir historis dari kedua kelas tersebut meningkat. Berikut peningkatan dari kelas XI MIPA 9 dan kelas XI MIPA 8.

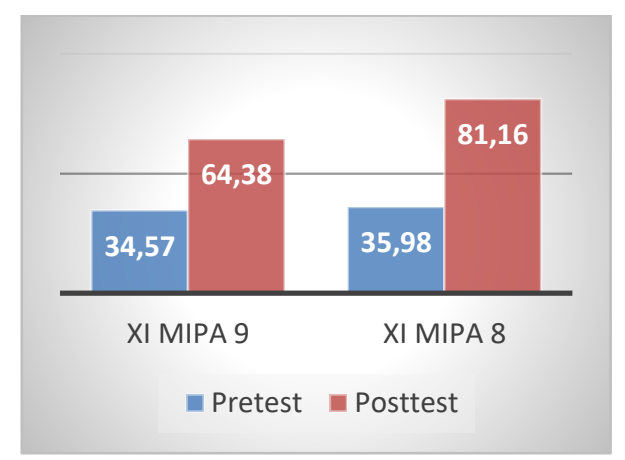

Gambar 2. Grafik Peningkatan Berpikir Historis Melalui Test

Berdasarkan grafik tersebut dapat dilihat bahwa kelas eksperimen dan kelas kontrol mengalami peningkatan. Pada pretest kelas kontrol memiliki rata-rata 34,57 sedangkan rata-rata hasil posttest yaitu 64,38 . Kelas eksperimen memiliki nilai rata-rata pretet 35,98 sedangkan pada rata-rata posttest yaitu 81,16 . Hal ini tentu saja merupakan kenaikan yang cukup 
signifikan. Kenaikan ini didapatkan setelah kedua kelas tersebut mendapatkan perlakuan (treatment). Namun disini kelas eksperimen memiliki rata-rata posttest lebih tinggi dibandingankan kelas kontrol. Kelas eksperimen ini mendapatkan perlakuan dengan menerapkan media permainan monopoli sedangkan untuk kelas kontrol dengan menggunakan media powerpoint.

Untuk melihat pengaruh dari penggunaan media tersebut, maka dilakukan uji hipotesis analisis independent sample $\mathrm{t}$ test ragam tidak homogen dengan program SPSS versi 25. Berikut merupakan hasil uji hipotesisnya:

Tabel 5. Hasil Uji Hipotesis

\begin{tabular}{|c|c|c|c|c|c|c|}
\hline Data & Mean & t Hitung & t Tabel & Df & $\begin{array}{l}\text { Sig (2- } \\
\text { tailed) }\end{array}$ & Keterangan \\
\hline Eksperimen & 81,16 & \multirow{2}{*}{6,248} & \multirow{2}{*}{2,000} & \multirow{2}{*}{60} & \multirow{2}{*}{0,00} & Ada \\
\hline Kontrol & 64,38 & & & & & Pengaruh \\
\hline
\end{tabular}

Sumber: Hasil Pengolahan Data

Hasil analisis uji independent sample $t$ test ragam tidak homogen atau t'aksen (equal variance not assumed) pada uji hipotesis menunjukan bahwa nilai $t$ hitung $>t$ tabel yaitu 6,248 $>2,000$. Atau bisa dilihat dengan membandingkan nilai sig (2-tailed) 0,00<0,05. Sehingga dengan demikian, maka Ha dalam penelitian ini diterima dan HO ditolak. Kesimpulannya maka terdapat pengaruh dari penggunaan media permainan monopoli sebagai media pembelajaran terhadap kemampuan berpikir historis pada mata pelajaran sejarah siswa kelas XI MIPA 8 SMA Negeri 1 Tasikmalaya. 
Melihat keefektifan media yang digunakan, selanjutnya dilakukan uji N-Gain. Berikut merupakan NGain Score dari kelas eksperimen dan kelas kontrol:

Tabel 6. Hasil N-Gain Score

\begin{tabular}{llll}
\hline Kelas & Skor Posttest & $\begin{array}{l}\text { Skor } \\
\text { Pretest }\end{array}$ & NGain Persen \\
\hline Eksperimen & 81,16 & 35,98 & 70,473 \\
Kontrol & 64,38 & 34,57 & 44,979 \\
\hline
\end{tabular}

Sumber: Hasil Pengolahan Data

Hasil pengujian N-Gain menurut tabel diatas menunjukan nilai NGain Score dalam bentuk persen untuk kelas eksperimen yaitu 70,473. Sehingga berdasarkan klasifikasi tafsiran N-Gain dalam bentuk persen dengan nilai tersebut bisa dikategorikan bahwa cukup efektif. Kesimpulannya, bahwa penggunaan media permainan monopoli terhadap kemampuan berpikir historis cukup efektif digunakan dalam proses pembelajaran.

Sedangkan untuk nilai N-Gain Score kelas kontrol yaitu 44,979 yang berarti kurang efektif (sesuai klasifikasi tafsiran N-Gain Persen). Hal ini dapat diartikan bahwa penggunaan media powerpoint dalam proses pembelajaran sejarah terhadap kemampuan berpikir historis kurang efektif digunakan. Sehingga berdasarkan dua nilai tersebut, bisa disimpulkan bahwa penggunaan media permainan monopoli terhadap kemampuan berpikir historis lebih efektif jika dibandingkan dengan penggunaan media powerpoint.

\section{PEMBAHASAN}

Berdasarkan hasil pengolahan data yang telah dilakukan, diperoleh bahwa hasil pre test dan post test kelas XI MIPA 8 mendapatkan hasil rata- 
rata 35,98 sebelum dilakukan treatment. Setelah dilakukan treatment dengan menggunakan media permainan monopoli rata-rata nya menjadi 81,16 . Pre test dan post test ini menggunakan soal uraian dengan indikator berpikir historis yang bertujuan untuk melihat keadaan berpikir historis. Rata-rata pretest 35,98 menunjukan bahwa tingkat kemampuan berpikir historis siwa terbilang cukup rendah, sedangkan pada posttest memiliki kenaikan yang cukup signifikan.

Hasil uji independent sample t-test analisis $\mathrm{t}^{\prime}$ ( $\mathrm{t}$ aksen) menunjukan bahwa nilai $\mathrm{t}$ hitung dari posttest eksperimen dan kontrol yaitu 6,248 sedangkan $\mathrm{t}$ tabelnya hanya 2,000. Berdasakan signifikasi 0,05 dan pengambilan keputusan $\mathrm{t}$ hitung $>\mathrm{t}$ tabel $(6,248>2,000)$ menunjukan adanya pengaruh dari penggunaan media yang digunakan. Atau untuk melihat pengaruh juga bisa dilihat melalui nilai sig-2 tailed. Nilai sig-2 tailed dari data statistik posttest ini yaitu 0,00. Nilai $0,00<0,05$ diartikan ada pengaruh dari penggunaan media yang digunakan.

Adanya pengaruh dari media yang digunakan menunjukan bahwa Ha diterima dan H0 ditolak. Sehingga hipotesis penelitian yaitu permainan monopoli sebagai media pembelajaran pada mata pelajaran sejarah Indonesia sub bahasan proklamasi kemerdekaan sampai terbentuknya pemerintahan Indonesia berpengaruh terhadap kemampuan berpikir historis siswa kelas XI MIPA 8 SMA Negeri 1 Tasikmalaya semester genap tahun ajaran 2019/2020 dinyatakan diterima dan terbukti memiliki pengaruh.

Melihat keefektifan dari media tersebut dapat dilihat dari hasil NGain Score. Nilai N-Gain Score dalam bentuk persen bagi kelas eksperimen yaitu 70,473 yang sesuai tafsiran N-Gain bentuk persen bahwa penggunaan 
media permainan monopoli tersebut cukup efektif. Sedangkan nilai N-Gain score dalam bentuk persen kelas kontrol yaitu 44,979 yang berarti bahwa media powerpoint yang digunakan kurang efektif dalam pembelajaran sejarah materi proklamasi kemerdekaan sampai terbentuknya pemerintahan Indonesia. Sehingga berdasarkan nilai N-Gain Score tersebut bisa disimpulkan bahwa efektifitas media permainan monopoli lebih tinggi daripada media powerpoint.

\section{KESIMPULAN}

Proses pembelajaran menggunakan media pembelajaran monopoli di XI MIPA 8 dimulai dengan membagi siswa kedalam beberapa kelompok kecil. Siswa dibagi menjadi 6 kelompok dengan anggota yang heterogen untuk mengikuti pembelajaran dengan menggunakan media. Penggunaan media pembelajaran berbasis permainan menjadi pilihan yang tepat jika diterapkan pada kelas ini. Media permainan yang digunakan adalah media permainan monopoli yang sudah di set dengan materi peristiwa proklamasikemerdekaan dampai terbentuknya pemerintahan Indonesia yang disesuaikan dengan penjabaran indikator berpikir historis. Pembelajaran dengan menggunakan media ini dilakukan secara bergantian melalui perwakilan kelompok yang maju ke depan.

Teknis belajar dengan permainan monopoli secara garis besar dilakukan seperti permainan monopoli biasanya. Hanya saja dalam belajar dengan media permainan monopoli ini setiap kelompok tidak hanya dituntut untuk memperkaya kelompoknya saja, melainkan harus 
berlomba-lomba dalam memperebutkan skor yang didapat. Perolehan skor bisa didapatkan dengan menjawab atau menjelaskan kartu cerita, kartu penyelesaian dan kartu perpustakaan.

Berdasarkah hasil analisis independent sample $t$ test ragam tidak homogen $\left(t^{\prime}\right)$ menunjukan bahwa $t$ hitung $>t$ tabel yaitu 6,248 $>2,000$ menunjukan adanya pengaruh dari penggunaan media yang digunakan. Atau untuk melihat pengaruh juga bisa dilihat melalui nilai sig-2 tailed. Nilai sig-2 tailed dari data statistik posttest ini yaitu 0,00 . Nilai $0,00<0,05$ diartikan ada pengaruh dari penggunaan media yang digunakan.

Efektifitas dari media permainan monopoli terhadap kemampuan berpikir historis dalam pembelajaran sejarah materi proklamasi kemerdekaan berdasarkan hasil N-Gain Score persen yaitu 70,473. Tafsiran dari nilai tersebut sesuai tafsiran N-Gain bentuk persen bahwa penggunaan media permainan monopoli tersebut cukup efektif digunakan di kelas XI MIPA 8 untuk meningkatkan kemampuan berpikir historis.

\section{DAFTAR PUSTAKA}

[1] Arsyad, Azhar. (2007). Media Pembelajaran. Jakarta:PT Grafindo Persada.

[2] Bennett, Neville, dkk. (2005). Teaching through play teacher's and classroom practice. Jakarta: Grasindo.

[3] Sa'dun Akbar, Iffah QA, Febrianti YS, Dina Ferisa, Wahyu W., Rakyan Paranimmita S. K. (2015). "Development And Implementation of Thematic Teaching Instrument To Improve Quality on Process and Result of Learning in Elementary School". International Conference on Education and Training; Quality Improvment In Education \& Training (p. 461). Malang: FIP UNM. 
[4] Shavab, Oka Agus Kurniawan dan Miftahudin, Zulpi. (2019). "Kontribusi Model Pembelajaran Cooperative Learning Tipe Buzz Group Materi Perang Dingin Pada Mata Kuliah Sejarah Kontemporer Eropa Terhadap Hasil Belajar Kognitif Mahasiswa". Candrasangkala, 5(2): 14-23.

[5] Sumantri, Yeni Kurniawati dan Yulianti, Iing. (2019). "Folk Game As An Alternative Model Of Creative History Learning". Proceeding: The 4 th International Seminar on Social Studies and History Education (ISSSHE) 2019. Bandung: Sekolah Pascasarjana PIPS.

[6] Sofiani, Yulia, \& Shavab, Oka Agus Kurniawan. (2018). “Kontribusi Model Pembelajaran Kooperatif Learning Tipe Group Investigation Berbantuan Learning Management System (LMS) Berbasis Edmodo dalam Meningkatkan Kemampuan Berpikir Historis Mahasiswa Calon Guru Sejarah". Indonesian Journal of History Education (IJHE), 6(2): 115-122.

[7] Wineburg, S. (2006). Berpikir historis: Memetakan Masa Depan, Mengajarkan Masa Lalu. (Terjemahan Masri Maris). Jakarta: Yayasan Obor Indonesia. 